\title{
Extraterritorial application of the right to life on the high sea. Commentary to the Views adopted by the Human Rights Committee of 27 January 2021, A.S., D.I., O.I. and G.D. against Italy, Communication No. 3042/2017
}

\author{
Eksterytorialne stosowanie prawa do życia na pełnym morzu. Glosa do opinii \\ Komitetu Praw Człowieka z dnia 27 stycznia 2021 r., A.S., D.I., O.I. i G.D. przeciwko \\ Włochom, wniosek nr 3042/2017 \\ Экстерриториальное применение права на жизнь в открытом море. \\ Комментарий к заключению Комитета по правам человека от 27 января 2021 \\ года, A.S., D.I., O.I. і G.D. против Италии, заявление № 3042/2017
}

\author{
BARTOSZ PACHOLSKI \\ M.A., University of Szczecin \\ e-mail: bartosz.pacholski@usz.edu.pl, https://orcid.org/0000-0002-4328-4491
}

\begin{abstract}
Summary: The subject matter of this commentary, which instigates the Views of the Human Rights Committee of 27 January 2021, is the protection of one of the fundamental human rights - the right to life. The Committee, as an authority appointed to oversee compliance with the International Covenant on Civil and Political Rights, had to decide on the issue of Italy's responsibility for failing to provide assistance to a boat in distress, even if the area in which the vessel was located was not within the territory of this state and other acts of international law attribute the responsibility for executing the rescue operation to a third country. According to the Committee's views, which applied extraterritorial approach to the protection of the right to life, whenever states have the opportunity to take action for the protection of human rights they should do everything possible in a given situation to help people in need.
\end{abstract}

Key words: Human Rights Committee, right to life, extraterritoriality, Italy, migration, UN, positive obligations

Streszczenie: Przedmiotem glosowanej opinii Komitetu Praw Człowieka z dnia 27 stycznia 2021 r. jest ochrona jednego z podstawowych praw człowieka o charakterze zasadniczym - prawa do życia. Komitet jako organ powołany do kontroli przestrzegania Międzynarodowego paktu praw obywatelskich i politycznych musiał rozstrzygnąć kwestię odpowiedzialności Włoch za brak udzielenia pomocy zagrożonej zatonięciem łodzi, nawet gdy dany obszar nie znajduje się w obrębie terytorium państwa, a inne akty prawa międzynarodowego wskazują państwo trzecie jako odpowiedzialne za prowadzenie akcji ratunkowej. Zgodnie z opinią Komitetu, stosującego eksterytorialne podejście do ochrony prawa do życia, w każdej sytuacji, gdy państwa mają możliwość podjęcia działań w przedmiocie ochrony praw człowieka, powinny uczynić wszystko, co w danej sytuacji jest możliwe, aby pomóc osobom w potrzebie.

Słowa kluczowe: Komitet Praw Człowieka, prawo do życia, eksterytorialność, Włochy, migracja, ONZ, obowiązki pozytywne

Резюме: Предметом рассматриваемого заключения Комитета по правам человека от 27 января 2021 года является защита одного из основных прав человека существенного характера - права на жизнь. Комитет, как орган, созданный для контроля за соблюдением Международного пакта о гражданских 
и политических правах, должен был решить вопрос об ответственности Италии за неоказание помощи судну, находящемуся под угрозой затопления, даже если данный район не находится на территории государства, а другие акты международного права назначают третье государство ответственным за проведение спасательной операции. По мнению Комитета, применяющего экстерриториальный подход кзащите права на жизнь, в любой ситуации, когда государства в состоянии предпринять действияпо защите прав человека, они должны сделать все возможное в данной ситуации, чтобы помочь нуждающимся.

Ключевые слова: Комитет по правам человека, право на жизнь, экстерриториальность, Италия, миграция, $\mathrm{OОH,} \mathrm{позитивные} \mathrm{обязательства}$

\section{Introduction}

According to current statistics, ${ }^{1}$ the number of fatalities among immigrants trying to reach Europe across the Mediterranean Sea in 2014-2021 exceeded 21,000. The United Nations, in a 2020 report from "Special Rapporteur on Extrajudicial, Summary or Arbitrary Executions" (12.10.2020), compared the Mediterranean Sea to an immense mass grave, noting that migrants were killed by a deadly combination of human traffickers' violence and greed, and States' failure to protect. ${ }^{2}$ The views in question concern one of the first tragedies on the Mediterranean Sea, which took place in 2013, that is before the peak of the migration crisis in Europe that occurred in $2015 .^{3}$ A ship carrying more than 400 immigrants started to sink in the Mediterranean Sea, which led to the death of more than 200 people, including 60 children. ${ }^{4}$ It was considered one of the worst tragedies of the European refugee crisis. ${ }^{5}$ The Human Rights Committee (HRC), in an opinion issued on 27 January 2021, ${ }^{6}$ examined the responsibility of the countries that had participated in the rescue operation

1 International Organization for Migration, Missing Migrants Project, https://missingmigrants.iom.int/ region/mediterranean [access: 3.05.2021].

2 A. Callamard, Report of the Special Rapporteur of the Human Rights Council on Extrajudicial, Summary or Arbitrary Executions, https://undocs.org/en/A/75/384 [access: 3.05.2021], as quoted in: G. Citroni, No More Elusion of Responsibility for Rescue Operations at Sea: the Human Rights Committee's Views on the Case A.S., D.I., O.I. and G.D. v. Italy and Malta, Opinio Juris, https://opiniojuris. org/2021/03/09/no-more-elusion-of-responsibility-for-rescue-operations-at-sea-the-human-rightscommittees-views-on-the-case-a-s-d-i-o-i-and-g-d-v-italy-and-malta/ [access: 4.05.2021].

3 Directorate-General for Communication (European Commission), UE a kryzys uchodźczy, DOI: $10.2775 / 090543$.

4 Views adopted by the Committee under article 5 (4) of the Optional Protocol, concerning Communication No. 3042/2017, $\$ 2.3$, https://tbinternet.ohchr.org [access: 4.05.2021].

5 A. Momigliano, Italian Forces Ignored a Sinking Ship Full of Syrian Refugees and Let More than 250 Drown, Says Leaked Audio, The Washington Post, https://www.washingtonpost.com/news/worldviews/wp/2017/05/09/italian-forces-ignored-a-sinking-ship-full-of-syrian-refugees-and-let-morethan-250-drown-says-leaked-audio/ [access: 4.05.2021].

6 Views adopted by the Committee... 
regarding the need to save human life at sea even if the location of the accident was not directly in a country's territorial waters. The issues discussed, pertaining to the protection of one fundamental human right - the right to life - deserve a special focus due to the Committee's broad approach to responsibilities of states in terms of protecting the right to life and providing necessary aid also when acts of international law other that the International Covenant on Civil and Political Rights $(\mathrm{ICCPR})^{7}$ do not directly stipulate the state's sovereignty over a given area, even if at the same time jurisdiction of more than one country may apply.

It also needs to be pointed out that originally the communication was submitted against Italy and Malta jointly, but the Committee decided that they should be examined separately. Even though the Committee recognised that Malta also exercised jurisdiction at the location of the incident, the complaint was deemed inadmissible since domestic remedies had not been exhausted. ${ }^{8}$

\section{Public international law analysed}

The HRC is a body appointed on 28 September 1976 under Article 28 ICCPR by the Covenant's States Parties. ${ }^{9}$ Its main task is to inspect the process of implementing provisions included in the ICCPR and it is the first universal body that was vested with the responsibility for monitoring the observance of human rights regulated in a binding act of international law. ${ }^{10}$ Given the scope of its jurisdiction to examine both individual and cross-country cases and the procedure of examining complaints, it is a quasi-judicial organ. ${ }^{11}$

In the views in question, the HRC had to decide whether Italy was guilty of violating Article 6 ICCPR which, in subsection 1, reads: "Every human being has the inherent right to life. This right shall be protected by law. No one shall be arbitrarily deprived of his life."

7 International Covenant on Civil and Political Rights opened for signature at New York on 19 December 1966, UNTS, vol. 999, p. 171.

8 Decision adopted by the Committee under the Optional Protocol, concerning Communication No. 3043/2017, https://tbinternet.ohchr.org [access: 5.05.2021].

9 Wielka Encyklopedia Prawa, vol. 4. Prawo międzynarodowe publiczne, eds. J. Symonides, D. Pyć, Warszawa 2014, p. 167.

10 KomitetPraw Człowieka ONZ. Wybórorzecznictwa, eds. R. Wieruszewski, A. Gliszczyńska, K. Sękowska-Kozłowska, Warszawa 2009, p. 9.

11 I.a. in: Wielka Encyklopedia Prawa, p. 168; R. Wieruszewski, Komitet Praw Człowieka, in: Mechanizmy ochrony praw człowieka w ramach ONZ. Analiza systemowa, ed. R. Wieruszewski, Warszawa 2017, p. 5. 
The right to life, due to its basic and fundamental nature, is sometimes called "part of the core of all human rights." 12 A similar understanding of the nature of this right is emphasised in the views of the Committee, in which we notice, i.a., that complaints about violations of other articles of the Covenant do not have to be examined if an infringement of Article 6 is detected, because other possible violations will be "absorbed" by the infringements of the most important right, that is the right to life. ${ }^{13}$ The Committee also confirmed this thesis in the views in question, which only confirms the momentous and superior character attributed to the right to life.

\section{Facts}

The authors of the communication are a Palestine national and Syrian citizens, acting also on behalf of their families, who on 11 October 2013 boarded a fishing boat heading from Libya towards Europe. After a few hours of the voyage the vessel was damaged, which meant that large quantities of water entered the boat and posed a threat to life of those on board. The first call about a sinking ship was received between 11 and 12.26 p.m. by the Maritime Rescue Coordination Centre Rome (MRCC Rome), which then proceeded to locate the damaged vessel. After establishing that the boat was in an area that, according to the International Convention on Maritime Search and Rescue, concluded in Hamburg on 27 April 1979 (SAR convention) ${ }^{14}$ falls under Malta's SAR area, MRCC Rome gave all information to the Rescue Coordination Centre of Malta (RCC Malta), which accepted the responsibility for coordinating the rescue mission. It is worth noting that the scope of responsibilities under the SAR convention was a subject of dispute - RCC Malta assumed the formal role of coordinator of the rescue mission and the location of the shipwreck was indeed in the SAR area of Malta's jurisdiction. However, in fact the boat was 118 nautical miles from Malta and only 61 nautical miles from Lampedusa, an Italian island. ${ }^{15}$ What is more, according to recordings of communication between the Italian Navy Command and ITS Libra revealed by the media, the Ital-

12 B. Latos, Klauzula derogacyjna i limitacyjna w europejskiej konwencji o ochronie praw człowieka i podstawowych wolności, Warszawa 2008, p. 103.

13 A. Gliszczyńska-Grabias, in: Międzynarodowy pakt praw obywatelskich (osobistych) i politycznych. Komentarz, ed. R. Wieruszewski, Warszawa 2012, article 6.

14 International Convention on Maritime Search and Rescue (SAR) concluded at Hamburg on 27 April 1979, 1403 UNTS.

15 A. Momigliano, Italian Forces... 
ian navy ship was closest to the location of the incident, despite which it did not undertake a rescue operation, but actually - according to the authors of the communication who cite media coverage - departed from the location of the shipwreck upon instruction from her command. ${ }^{16}$ ITS Libra was engaged in the rescue operation only at about 17:00 p.m., that is at least 4.5 hours after the first information about people in distress on board and the moment the boat capsized. It ought to be highlighted that in its official position expressed to the Committee, Italy did not refer to these challenges - it was emphasised that ITS Libra, even before the official communication from RCC Malta about the vessel capsizing, had been heading towards the place of the shipwreck and once it got there it took the role of an on-scene coordinator, thus saving many of those on board.

\section{Views of the Human Rights Committee}

When proceeding to the examination of the case, the Committee verified whether the formal conditions for the admissibility of a communication had been satisfied correctly. According to Italy's argumentation, the Committee did not have the authority to examine the communication because the issue in question did not meet the requirements stipulated in Article 1 of the Optional Protocol to the ICCPR, ${ }^{17}$ that is the vessel was shipwrecked outside Italy's territorial waters and thus the location of the accident did not fall under this country's jurisdiction. When examining this issue, the Committee referred to the 1986 General Comment No. 15: The Position of Aliens Under the Covenant, ${ }^{18}$ which stipulates that if the rights set forth in the Covenant apply to everyone, irrespective of reciprocity, and irrespective of his or her nationality or statelessness, thus to asylum seekers, refugees and other persons who may find themselves in the territory or subject to the jurisdiction of the State party - this regulation relates to those within the power or effective control of the forces of a State party acting outside its territory as well. Then the body of decisions of the Committee itself was referred to - to be more specific, the 2019

16 Ibidem.

17 Optional Protocol to the International Covenant on Civil and Political Rights adopted and opened for signature, ratification and accession by General Assembly resolution 2200A (XXI) of 16 December 1966, UNTS, vol. 999, p. 171.

18 CCPR General Comment No. 15: The Position of Aliens Under the Covenant Adopted at the Twenty-seventh session of the Human Rights Committee on 11 April 1986, https://www.refworld.org/ docid/45139acfc.html [access: 5.05.2021]. 
General Comment No. 36 to Article 6: right to life, ${ }^{19}$ which prescribes that: "In light of article 2, paragraph 1, of the Covenant, a State party has an obligation to respect and to ensure the rights under article 6 of all persons who are within its territory and all persons subject to its jurisdiction, that is, all persons over whose enjoyment of the right to life it exercises power or effective control. This includes persons located outside any territory effectively controlled by the State, whose right to life is nonetheless impacted by its military or other activities in a direct and reasonably foreseeable manner. States parties must respect and protect the lives of individuals located in places that are under their effective control, such as occupied territories, and in territories over which they have assumed an international obligation to apply the Covenant. States parties are also required to respect and protect the lives of all individuals located on marine vessels and aircraft registered by them or flying their flag, and of those individuals who find themselves in a situation of distress at sea, in accordance with their international obligations on rescue at sea." ${ }^{20}$ In effect, the Committee's objective in the views in question was to appropriately apply criteria described in General Comment No. 36 so as to decide whether the alleged victims could be considered to have been within the power or effective control of the State party, even though the incident took place outside its territory. The Committee concluded that in the particular circumstances of the case, a special relationship of dependency had been established between the individuals on the vessel in distress and Italy, which was determined by these facts:

- the duty to cooperate in rescue operations and to save life at sea, which binds all States regardless of where a shipwreck occurs;

- the Italian authorities answered the first call from the vessel, and indicated to those on board that they would be rescued;

- an Italian naval unit - about one hour away - was closer to the sinking vessel than any Maltese units. ${ }^{21}$

The HRC ultimately concluded that persons on board the ship "were directly affected by the decisions taken by the Italian authorities in a manner that was reasonably foreseeable in light of the relevant legal obligations of Italy, and that they were thus subject to Italy's jurisdiction for the purposes of the Covenant, notwithstanding

19 HRC General comment No. 36 to Article 6: right to life of 3 September 2019, https://undocs.org/ CCPR/C/GC/36 [access: 5.05.2021].

20 Ibidem, $\S 63$.

21 P. Busco, Not All that Glitters Is Gold: the Human Rights Committee's Test for the Extraterritorial Application of the ICCPR in the Context of Search and Rescue Operations, Opinio Juris, https://opiniojuris. org/2021/03/02/not-all-that-glitters-is-gold-the-human-rights-committees-test-for-the-extraterritorialapplication-of-the-iccpr-in-the-context-of-search-and-rescue-operations/ [access: 5.05.2021]. 
the fact that they were within the Maltese search and rescue region and thus also subject concurrently to the jurisdiction of Malta." ${ }^{22}$

In its examination of the case, the Committee again referred to General Comment No. 36, emphasising this time the responsibility of states to adopt any appropriate laws or other measures in order to protect life from all reasonably foreseeable threats. Recognising Malta's principal responsibility for the rescue operation, the State party had not provided a clear explanation for what appears to have been a failure to promptly respond to a distress call, prior to the assumption of responsibility for the search and rescue operation by the Maltese authorities. In the Committee's opinion, Italy, despite being the first country that the persons on board contacted, did not show an interest in the situation or in the status of the search and rescue operation. What it more, it also failed to explain convincingly why ITS Libra, located in the immediate vicinity of the vessel in distress, only headed towards the survivors after many hours of delay, even despite official calls from Malta that was coordinating the search and rescue operation. Finally, the Committee noted that the State party had not clearly explained or refuted the authors' claim that intercepted phone calls indicate that the ITS Libra was ordered to sail away from the vessel in distress. In the summary of observations on the facts presented, the Committee decided that Italy had failed to show that it had met its due diligence obligations under article 6 (1) of the Covenant.

In reference to the subject matter of the on-going domestic proceedings, the Committee concluded that Italy's argument about the exceptional complexity of the case due to a high number of stakeholders involved and the difficult reconstruction of facts was not substantiated in reality. The Committee noticed that Italy only referred to general statements not substantiated with arguments, and what is more, it failed to provide an anticipated time of closing the case at the domestic stage. In these circumstances, the Committee considered that the State party had failed to show that it had met its duty to conduct a prompt investigation of the allegations relating to a violation of the rights to life, and that, as a result, it had violated its obligations under article 6 (1) read in conjunction with article 2 (3) of the Covenant.

As mentioned before, after the Committee concluded that Article 6 was violated and that this article truly "absorbed" the remaining allegations raised by the authors, it decided not to examine Italy's violation of Article 7 ICCPR separately. In effect, Italy was obliged to make full reparation to individuals whose Covenant's rights had been violated and to proceed with an independent and effective investigation in a prompt manner and, if found necessary, to prosecute and try those

22 Views adopted by the Committee... 
responsible for the death and disappearance of the authors' relatives. In accordance with the course of the proceedings, Italy was obliged to publish and disseminate the Committee's views, put relevant procedures in place to prevent such incidents from happening in future and present the Committee with a report on actions taken within half a year from the issuance of these views.

\section{Assessment of the views commented on herein}

The basic problem that the Committee had to deal with in the context of the subject matter discussed was to decide whether ICCPR provisions applied to the facts of the case. According to the regulation of Article 2 ICCPR, each State Party undertakes to respect and to ensure to all individuals within its territory and, subject to its jurisdiction, the rights recognised in the Covenant. In view of the above, the key issue is to answer the question whether the location of the shipwreck fell under Italy's jurisdiction. Seemingly it may be assumed that the subject matter does not need an in-depth analysis and the answer to this question is negative, even only due to the indisputable nature of the fact that the location of the shipwreck was not within Italy's maritime territory and because in accordance with the provisions of the SAR convention, Malta was obliged to organise and carry out the search and rescue operation since the incidents at issue took place within its SAR area. However, the fact that it was MRCC Rome that received the first call from persons on board about the vessel being in distress and that the Italian navy ship was already at that moment relatively close to the shipwreck location means that the case was complicated not only in terms of the laws in force but, most of all, the assessment of facts that are the basis for their analysis. Thus, it was Italy that had the opportunity to respond in the situation of a threat to life of persons on board the ship and the implicated responsibility to act, which is discussed below.

When examining the facts presented, the Committee had the opportunity for the first time to apply in practice the functional approach it had first articulated in General Comment 36 (2018) on the right to life, and to do so in the most difficult of contexts - the applicability of positive obligations of protection. ${ }^{23}$ The universal, inherent and inalienable nature of human rights means that the conviction about the extraterritorial application of the norms of public international law intended

23 M. Milanovic, Drowning Migrants, the Human Rights Committee, and Extraterritorial Human Rights Obligations, Blog of the European Journal of International Law, https://www.ejiltalk.org/drowningmigrants-the-human-rights-committee-and-extraterritorial-human-rights-obligations/ [access: 5.05.2021]. 
to protect fundamental human rights, including the right to life, is not subject to dispute. Such situations usually occur during an occupation of territory ("spatial model") or exercise of physical authority over persons ("personal model"), but - as noted by P. Busco - human rights bodies have rightly expanded the test to cover additional forms of exercise of authority by States that do not fall squarely into the two canonic models. ${ }^{24}$ The Committee presented such a modern and functional approach. The analysis of the views in question may elicit the conclusion that each time when a given state has the power to exercise functions that have an impact on human rights of individuals in a direct and reasonably foreseeable manner, those individuals are within the jurisdiction of the State. ${ }^{25}$ In other words, in a situation where states have any possibility to protect human rights, they are obliged to take measures. The Committee attempts to limit such a broad scope of responsibilities of states by invoking the concept of 'a special relationship of dependency' between the people in distress and Italy, ${ }^{26}$ which was determined by facts - Italy received the first information about the sinking ship, ensured passengers that help would be on its way, stayed in continuous contact with RCC Malta from the very first call and it was their ship that was the closest to the location of the incident. To sum up, Italy had the opportunity to help the sinking vessel in this case - that is to say, it had the opportunity to protect the right to life of people on board the ship, and because it failed to respond appropriately, it was guilty of violating Article 6 ICCPR.

It ought to be noted that the Committee's views were adapted by a relatively small majority - 9 members believed that ICCPR was violated (as many as 6 members thought the opposite). Interestingly, one of the opposing members was Prof. Yuval Shany - the theorist of the functional approach to jurisdiction endorsed in General Comment No. 36. In a joint opinion with two other Committee members it was emphasised that the majority failed to distinguish situations in which States have the potential to place individuals under their effective control from situations involving the actual placement of individuals under effective State control. ${ }^{27}$ They note that the power or effective control occurs only where the vessel capable of brining help is at the scene, not in the proximity of the location. A. Zimmermann (also against Malta's case) zeroes in on the proximity issue, and is concerned about disincentivising states from deploying ships in areas where boats in distress might be in order to avoid

\footnotetext{
24 P. Busco, Not All that Glitters Is Gold...

25 Ibidem.

26 E. Mavropoulou, The Right to Life: Italy found by UN in Violation of the Right to Life of Migrants at Sea, Human Rights at Sea, https://www.humanrightsatsea.org/2021/01/28/the-right-to-life-italy-foundby-un-in-violation-of-the-right-to-life-of-migrants-at-sea/ [access: 5.05.2021].

Annex: 1, Individual Opinion of Yuval Shany, Christof Heyns and Photini Pazartzis (dissenting).
} 
a situation of 'dependency', emphasising the need for a coherent regulation of collective action in rescuing migrants in distress in a separate legal regime. ${ }^{28}$ Therefore, it seems that some Committee members see these views as a step too far that expands the scope of the obligations and responsibility of states. As aptly noted by A. Zimmermann, such a decision might eventually have the very unfortunate effect of States that are party to the Covenant no longer being willing to undertake such obligations, and respectively might even try to avoid approaching boats in distress so as to avoid any impressions of a 'special relationship of dependency' having been created. ${ }^{29}$

It is worth pointing out that the settling of the case discussed was a natural direction for the Committee that fits within its existing body of decisions, since it is an authority tasked with enforcing respect for human rights. The development of the concept of extraterritorial responsibility of states is, therefore, an anticipated and safe decision at whose foundation lies a conviction of the need to act for the protection of human rights whenever they are presented with such an opportunity. One must at the same time ponder on whether the Committee's views would have been different if the facts had turned out to be more complicated. Let us envisage a hypothetical situation - a ship with an unidentified number of passengers on board is within Italy's maritime territorial waters and is heading towards a port in Lampedusa. The crew do not react to attempts made to contact them by the maritime authorities of Italy which has a sovereign territorial jurisdiction in this territory. Moreover, a patrol vessel is sent and calls the crew directly to identify themselves. They do not answer the calls either and at the same time come dangerously close to the port. How should the state respond in this situation? Would the Committee also take a similar position in the case of conflict between the principle of sovereign territorial authority, which is a basic principle of international law, and the right of those on board this vessel to life? It would be immensely interesting to learn the Committee's views in the event of a collision of the fundamental basis of the international law order and the human rights protection system of fundamental importance.

\section{Conclusion}

While positively assessing the views of the Committee, one must remember that for the first time in its history the HRC stated that its decision refers solely to the pre-

\footnotetext{
28 M. Milanovic, Drowning Migrants, the Human Rights Committee...

29 Annex: 2, Individual Opinion of Andreas Zimmermann (dissenting).
} 
sented facts ('in the particular circumstances of the case'), which is undoubtedly an expression of caution on behalf of the Committee members in the extraterritorial application of the ICCPR in the context of search and rescue operations. As noted at the beginning of this commentary, the right to life is a foundation of the system of human rights protection, whereby ICCPR states-parties must do everything in their power to uphold this right. States should use all available resources where lives are in danger, even if formal responsibility for assistance is vested in another actor. States should cooperate effectively in this regard and not pass the buck to one another. In a situation of any threat to the right to life, solidarity and mutual assistance in operations should be the first response. Therefore, it is not surprising that the Committee, while considering the facts, decided that the alleged victims had been within the power or effective control of Italy. Although the HRC resorts to this concept of 'special relationship of dependency' for the first time, it remains to be seen ${ }^{30}$ whether this concept can reshape states' responsibilities under international law in the context of maritime search and the rescue of migrants and refugees at sea. ${ }^{31}$

\section{Translated by Agnieszka Kotula}

\section{Bibliography}

Busco P., Not All that Glitters Is Gold: the Human Rights Committee's Test for the Extraterritorial Application of the ICCPR in the Context of Search and Rescue Operations, Opinio Juris, https://opiniojuris.org/2021/03/02/not-all-that-glitters-is-gold-the-human-rightscommittees-test-for-the-extraterritorial-application-of-the-iccpr-in-the-context-ofsearch-and-rescue-operations/ [access: 05.05.2021].

Callamard A., Report of the Special Rapporteur of the Human Rights Council on Extrajudicial, Summary or Arbitrary Executions, https://undocs.org/en/A/75/384 [access: 3.05.2021].

Citroni G., No More Elusion of Responsibility for Rescue Operations at Sea: the Human Rights Committee's Views on the Case A.S., D.I., O.I. and G.D. v. Italy and Malta, Opinio Juris, https:// opiniojuris.org/2021/03/09/no-more-elusion-of-responsibility-for-rescue-operations-at-seathe-human-rights-committees-views-on-the-case-a-s-d-i-o-i-and-g-d-v-italy-and-malta/ [access: 4.05.2021].

30 Failure to change states' practices in this regard (after the Committee decided in the case investigated) is described by M. Milanovic, Drowning Migrants in the Mediterranean and the ICCPR, Again, Blog of the European Journal of International Law, https://www.ejiltalk.org/drowning-migrants-in-the-mediterranean-and-the-iccpr-again/ [access: 9.05.2021].

31

E. Mavropoulou, The Right to Life... 
Directorate-General for Communication (European Commission), UE a kryzys uchodźczy, DOI:10.2775/090543.

Gliszczyńska-Grabias A., in: Międzynarodowy pakt praw obywatelskich (osobistych) i politycznych. Komentarz, ed. R. Wieruszewski, Warszawa 2012.

International Organization for Migration, Missing Migrants Project, https://missingmigrants. iom.int/region/mediterranean [access: 3.05.2021].

Komitet Praw Człowieka ONZ. Wybór orzecznictwa, eds. R. Wieruszewski, A. Gliszczyńska, K. Sękowska-Kozłowska, Warszawa 2009.

Latos B., Klauzula derogacyjna i limitacyjna w Europejskiej konwencji o ochronie praw człowieka i podstawowych wolności, Warszawa 2008.

Mavropoulou E., The Right to Life: Italy Found by UN in Violation of the Right to Life of Migrants at Sea, Human Rights at Sea, https://www.humanrightsatsea.org/2021/01/28/ the-right-to-life-italy-found-by-un-in-violation-of-the-right-to-life-of-migrants-at-sea/ [access: 5.05.2021].

Milanovic M., Drowning Migrants in the Mediterranean and the ICCPR, Again, Blog of the European Journal of International Law, https:/www.ejiltalk.org/drowningmigrants-in-the-mediterranean-and-the-iccpr-again/ [access: 5.05.2021].

Milanovic M., Drowning Migrants, the Human Rights Committee, and Extraterritorial Human Rights Obligations, Blog of the European Journal of International Law, https://www. ejiltalk.org/drowning-migrants-the-human-rights-committee-and-extraterritorialhuman-rights-obligations/ [access: 5.05.2021].

Momigliano A., Italian Forces Ignored a Sinking Ship Full of Syrian Refugees and Let More than 250 Drown, Says Leaked Audio, The Washington Post, https://www.washingtonpost. com/news/worldviews/wp/2017/05/09/italian-forces-ignored-a-sinking-ship-full-ofsyrian-refugees-and-let-more-than-250-drown-says-leaked-audio/ [access: 4.05.2021].

Wielka Encyklopedia Prawa, vol. 4. Prawo międzynarodowe publiczne, eds. J. Symonides, D. Pyć, Warszawa 2014.

Wieruszewski R., Komitet Praw Człowieka, in: Mechanizmy ochrony praw człowieka $w$ ramach ONZ. Analiza systemowa, ed. R. Wieruszewski, Warszawa 2017. 